\title{
Mechanisms of Bicarbonate Secretion: Lessons from the Airways
}

\author{
Robert J. Bridges \\ Department of Physiology and Biophysics, Rosalind Franklin University of Medicine and Sciences, \\ North Chicago, Illinois 60064 \\ Correspondence: bob.bridges@rosalindfranklin.edu
}

Early studies showed that airway cells secrete $\mathrm{HCO}_{3}^{-}$in response to cAMP-mediated agonists and $\mathrm{HCO}_{3}^{-}$secretion was impaired in cystic fibrosis (CF). Studies with Calu-3 cells, an airway serous model with high expression of CFTR, also show the secretion of $\mathrm{HCO}_{3}^{-}$when cells are stimulated with cAMP-mediated agonists. Activation of basolateral membrane hlK-1 K $\mathrm{K}^{+}$ channels inhibits $\mathrm{HCO}_{3}^{-}$secretion and stimulates $\mathrm{Cl}^{-}$secretion. CFTR mediates the exit of both $\mathrm{HCO}_{3}^{-}$and $\mathrm{Cl}^{-}$across the apical membrane. Entry of $\mathrm{HCO}_{3}^{-}$on a basolateral membrane $\mathrm{NBC}$ or $\mathrm{Cl}^{-}$on the NKCC determines which anion is secreted. Switching between these two secreted anions is determined by the activity of hIK-1 $\mathrm{K}^{+}$channels.

$\mathrm{T}_{\mathrm{p}}^{\mathrm{h}}$ he recognition that $\mathrm{HCO}_{3}^{-}$secretion is impaired in CF patients dates back to the studies of Hadorn and coworkers in the 1960s (Hadorn et al. 1968). These investigators showed that pancreatic $\mathrm{HCO}_{3}^{-}$and fluid secretion were diminished in $\mathrm{CF}$ patients. Moreover, $\mathrm{CF}$ patients were refractory to secretin, a cAMPmediated secretory agonist in the pancreas. These studies were confirmed by Gaskin et al. (1982) and Kopelman et al. (1985, 1988). Extensive transport studies of the exocrine pancreas have shown that $\mathrm{HCO}_{3}^{-}$is the primary anion secreted by the ductal cells, the predominate site of CFTR expression (Marino et al. 1991). The human pancreas can secrete a fluid of $130 \mathrm{~mm}$ $\mathrm{HCO}_{3}^{-}$(Schultz 1987). Secreted $\mathrm{HCO}_{3}^{-}$electrically draws $\mathrm{Na}^{+}$into the lumen and $\mathrm{H}_{2} \mathrm{O}$ follows osmotically. The secreted fluid and electrolytes serve to flush the digestive enzymes from the acini and ducts of the pancreas. Thus, impaired $\mathrm{HCO}_{3}^{-}$secretion results in poor clearance of the digestive enzymes, and their premature activation eventuates in the destruction of the pancreas in CF. We surmise that a similar sequela follows from impaired $\mathrm{HCO}_{3}^{-}$secretion in the submucosal glands and airways of $\mathrm{CF}$ patients. Indeed, several recent studies from Wine and coworkers have shown cAMP-stimulated fluid secretion is impaired from CFTRdeficient submucosal glands (Joo et al. 2006). Verkman and coworkers have also shown impaired fluid secretion from the submucosal glands of CF patients and shown that the secreted fluid is hyperviscous and acidic compared with glands from non-CF patients (Salinas et al. 2005; Song et al. 2006). Analogous to the pancreas, the submucosal glands secrete mucins, protease inhibitors, antibiotic peptides,

Editors: John R. Riordan, Richard C. Boucher, and Paul M. Quinton

Additional Perspectives on Cystic Fibrosis available at www.perspectivesinmedicine.org

Copyright (C) 2012 Cold Spring Harbor Laboratory Press; all rights reserved; doi: 10.1101/cshperspect.a015016

Cite this article as Cold Spring Harb Perspect Med 2012;2:a015016 
R.J. Bridges

and enzymes that must be flushed from the glands onto the airway surface epithelium (Basbaum et al. 1990). Moreover, the physical properties of mucus are intrinsically dependent on the composition of the fluid. Most notably, alterations in ionic strength, divalent cation concentration, and $\mathrm{pH}$ have profound effects on the viscoelastic properties of mucins (Forstner et al. 1976; List et al. 1978; Tam et al. 1981; Lin et al. 1993). In the pancreas, the $\mathrm{pH}$ of the ductal fluid plays a critical role in regulating the activity of the exocytosed digestive enzymes. In contrast, very little is known regarding the electrolyte composition and $\mathrm{pH}$ of the submucosal gland fluid and the role it might play in the 1000-fold expansion that a mucin granule undergoes upon release and degranulation (Yeates et al. 1997; Verdugo and Hauser 2012). In addition, the surface epithelium must maintain a periciliary fluid of appropriate volume and composition to ensure proper mucociliary clearance (Randell and Boucher 2006; Boucher 2007). Adversely affected mucus leads to impaired mucociliary clearance from the submucosal glands and airway surface. The uncleared mucus then becomes a sink for bacterial binding, infection, and inflammation, thereby perpetuating a vicious cycle leading to further mucus secretion (Quinton 1999). This sequence of events is not restricted to the 40,000 individuals suffering from CF, but also occurs in more than 10 million patients suffering from COPD (chronic obstructive pulmonary disease) (Celli et al. 1995; O’Byrine et al. 1999). Thus, impaired fluid secretion by the submucosal glands or surface epithelium hinders clearance from the glands and airway surface. Until recently, $\mathrm{Cl}^{-}$was considered to be the secreted anion responsible for fluid secretion in the airways. However, recent studies suggest that $\mathrm{HCO}_{3}^{-}$secretion importantly contributes to the airway surface and submucosal gland microenvironments.

\section{AIRWAY CELLS SECRETE BICARBONATE}

Several early studies indicated that the shortcircuit current $\left(I_{\mathrm{SC}}\right)$, a measure of net electrolyte transport, across airway epithelia was not fully accounted for by the net movements of
$\mathrm{Na}^{+}$and $\mathrm{Cl}^{-}$. Instead, $35 \%-45 \%$ of the $I_{\mathrm{SC}}$ had to be attributed to an additional ion species. Ion substitution studies revealed that $\mathrm{HCO}_{3}^{-}$but not $\mathrm{Cl}^{-}$was required to observe a cAMP-stimulated increase in $I_{\mathrm{SC}}$ in airway monolayers (AlBazzaz et al. 1979, 1981; Welsh 1983). These early observations prompted Smith and Welsh (1992) to investigate $\mathrm{HCO}_{3}^{-}$secretion in normal and CF-cultured airway epithelia. The results of this investigation revealed that CAMP-stimulated $\mathrm{HCO}_{3}^{-}$secretion across normal but not $\mathrm{CF}$ airway epithelia. These investigators went on to conclude that $\mathrm{HCO}_{3}^{-}$exit at the apical membrane is through the $\mathrm{Cl}^{-}$channel, which is defectively regulated in CF epithelia. In addition, they suggested the possibility that a defect in $\mathrm{HCO}_{3}^{-}$secretion may contribute to the pathophysiology of CF pulmonary disease.

The intracellular microelectrode studies of Willumsen and Boucher (Willumsen et al. 1992), although designed for a different intent, provided important insight regarding the driving forces acting on $\mathrm{HCO}_{3}^{-}$and the question of why normal, but not, CF epithelia can secrete $\mathrm{HCO}_{3}^{-}$. These investigators observed that the intracellular $\mathrm{pHs}$ of normal and CF airway cells were equal (normal $=7.15 \pm 0.02$ vs. $\mathrm{CF}=$ $7.11 \pm 0.05)$, but that the apical membrane potentials $\left(V_{\text {ap }}\right)$ were different and of opposite polarity (normal $=-19 \pm 2 \mathrm{mV}$ vs. $\mathrm{CF}=3$ $\pm 5 \mathrm{mV}$ ). This difference has been confirmed in several additional studies by Boucher and coworkers (Boucher et al. 1988; Willumsen et al. 1989a,b). Thus, at an extracellular $\mathrm{HCO}_{3}^{-}$concentration of $25 \mathrm{~mm}$, an extracellular and intracellular $\mathrm{pCO}_{2}$ of $40 \mathrm{~mm} \mathrm{Hg}$, and a $\mathrm{pH}$ of 7.15, there is an outwardly directed driving force for $\mathrm{HCO}_{3}^{-}$secretion of $6 \mathrm{mV}$ across the apical membrane of normal cells. In contrast, in CF cells, there is an inwardly directed driving force for $\mathrm{HCO}_{3}^{-}$absorption of $16 \mathrm{mV}$ across the apical membrane. Therefore, provided there is a conductive pathway to mediate the movement of $\mathrm{HCO}_{3}^{-}$across the apical membrane, normal cells will secrete $\mathrm{HCO}_{3}^{-}$and CF cells will absorb $\mathrm{HCO}_{3}^{-}$. Although it is often suggested that impaired $\mathrm{Cl}^{-}$secretion must be corrected in $\mathrm{CF}$, it is noteworthy, given the above $V_{\mathrm{ap}} \mathrm{s}$ and the usual extracellular and intracellular $\mathrm{Cl}^{-}$ 
concentrations, that the net driving force acting on $\mathrm{Cl}^{-}$is in the absorptive direction for both normal $(9 \mathrm{mV})$ and CF $(31 \mathrm{mV})$ cells. Indeed, only after $\mathrm{Na}^{+}$transport is down-regulated or inhibited with amiloride is it possible to observe $\mathrm{Cl}^{-}$secretion in normal cells. It is generally accepted that the difference in $V_{\text {ap }}$ between normal and CF cells is due to the loss of CFTR channels and the higher $\mathrm{Na}^{+}$permeability in CF cells (Boucher et al. 1986, 1988; Boucher 1994a,b). Besides $\mathrm{Cl}^{-}$, CFTR also conducts $\mathrm{HCO}_{3}^{-}$, as shown in the studies of Gray et al. (1990) and Linsdell and coworkers (Linsdell et al. 1997; Tang et al. 2009; Li et al. 2011) and more recently by Ishiguro et al. (2009). Therefore, normal airway cells can secrete $\mathrm{HCO}_{3}^{-}$through CFTR, whereas $\mathrm{CF}$ cells show a $\mathrm{HCO}_{3}^{-}$impermeability. This reasoning leads us to assert that, in addition to abnormal $\mathrm{Cl}^{-}$and $\mathrm{Na}^{+}$transport, $\mathrm{HCO}_{3}^{-}$ transport is also dysfunctional in CF airway epithelia and that $\mathrm{HCO}_{3}^{-}$secretion and not $\mathrm{Cl}^{-}$ secretion is critical for normal surface airway epithelial function.

\section{STUDIES WITH Calu-3 CELLS}

A second line of evidence that $\mathrm{HCO}_{3}^{-}$secretion in the airways may be more important than previously appreciated comes from the studies of Wine and coworkers (Lee et al. 1998) and the results on Calu- 3 cells from my own group (Devor et al. 1999). Calu-3 cells are a human airway serous cell line developed by Wine and Widdicombe and coworkers (Shen et al. 1994). The Calu-3 cells were selected from among 12 lung adenocarcinomas as a cell line consistent with cell biological and electrophysiological characteristics of airway serous cells. Calu-3 cells form confluent monolayers with transepithelial resistances of several hundred ohm-centimeters squared $\left(\Omega \mathrm{cm}^{2}\right)$, express high levels of CFTR, and respond to both CAMP- and $\mathrm{Ca}^{2+}$-mediated agonists with changes in net transepithelial ion transport as measured by $I_{\mathrm{SC}}$ (Finkbeiner et al. 1993; Shen et al. 1994). In addition, the Calu-3 cells produce several serous cell-associated proteins including lysozyme, lactoferrin, serine leukoprotease inhibitor (SLP1), secretory component, and mucins (MUC1 and MUC2)
(Finkbeiner et al. 1993). The Calu-3 cells are now used by many laboratories as a serous cell model (Kelley et al. 1995; Grygorczyk et al. 1997; Liedtke et al. 1998; Al-Nakkash et al. 1999; Berger et al. 1999; Duszyk et al. 1999; Illek et al. 1999; Ito et al. 1999; Waters et al. 1999). Our studies on Calu-3 cells showed that they secrete $\mathrm{HCO}_{3}^{-}$rather than $\mathrm{Cl}^{-}$in response to cAMP-mediated agonists. In effect, the Calu-3 cells function as one would expect for a pancreatic ductal cell; however, a cell line of the latter is thus far unavailable. Calu-3 cells express high levels of CFTR, as do serous cells of the submucosal glands of the native epithelium (Puchelle et al. 1992; Engelhardt et al. 1994) and pancreatic ductal cells (Marino et al. 1991). In addition, Calu-3 cells express $\mathrm{Na}: \mathrm{HCO}_{3}^{-}$cotransporter isoforms pNBC1 (SLC4A4, NBCe1) and NBC4 (SLC4A5, NBCe2) in the basolateral membrane (Kreindler et al. 2006). Studies from Case and coworkers on pancreatic ducts (Ishiguro et al. 1996a,b) and the studies of my laboratory on Calu-3 cells (Devor et al. 1999) suggest that $\mathrm{HCO}_{3}^{-}$entry across the basolateral membrane is mediated by an NBC. If we assume that the transport phenotype expressed by Calu-3 cells accurately reflects native serous cells, then $\mathrm{HCO}_{3}^{-}$secretion must be important in the physiology of submucosal glands. In agreement with this hypothesis, the studies of Ballard and coworkers have shown that inhibitors of $\mathrm{HCO}_{3}^{-}$ secretion, acetazolamide, a carbonic anhydrase inhibitor, and DIDS, an inhibitor of $\mathrm{Cl}^{-}: \mathrm{HCO}_{3}^{-}$ exchangers as well as NBCs, caused mucus obstruction of the submucosal glands in secretagogue-stimulated porcine distal bronchi (Inglis et al. 1997, 1998; Trout et al. 1998). Furthermore, bumetanide, an inhibitor of the $\mathrm{Na}^{+}$:$\mathrm{K}^{+}: 2 \mathrm{Cl}^{-}$cotransporter (NKCC1) and thereby $\mathrm{Cl}^{-}$secretion failed to inhibit cAMP-induced gland fluid secretion (Corrales et al. 1984). Consistent with these results, the forskolin-stimulated increase in $I_{\mathrm{SC}}$ in Calu-3 cells is insensitive to bumetanide but is inhibited by acetazolamide and DNDS, another inhibitor of NBCs (Devor et al. 1999). Collectively, these studies lead us to conclude that $\mathrm{HCO}_{3}^{-}$secretion is important in the physiology of submucosal glands and the airway surface epithelium. 
R.J. Bridges

\section{MODEL FOR ANION SECRETION IN AIRWAY CELLS}

Our model for anion secretion in Calu-3 cells is illustrated in Figure 1. Forskolin-stimulated Calu-3 cells secrete $\mathrm{HCO}_{3}^{-}$by an electrogenic mechanism, that is, $\mathrm{Cl}^{-}$-independent, serosal $\mathrm{Na}^{+}$-dependent, serosal bumetanide-insensitive and inhibited by serosal disulfonic stilbene (DNDS) as judged by transepithelial currents, isotope fluxes, and the results of ion substitution, pharmacology, and $\mathrm{pH}$ studies (Devor et al. 1999). However, Calu-3 cells are not limited to the secretion of $\mathrm{HCO}_{3}^{-}$. Instead, when stimulated by 1-EBIO (1-ethyl-2-benzimidazolinone), an activator of the basolateral membrane, $\mathrm{Ca}^{+}$-activated CTX-sensitive, $\mathrm{K}^{+}$channels (hIK1, KCNN4), Calu-3 cells secrete $\mathrm{Cl}^{-}$by an electrogenic bumetanide-sensitive mechanism, and $\mathrm{HCO}_{3}^{-}$secretion is diminished. Moreover, when stimulated by both forskolin and 1-EBIO, the secretion of $\mathrm{HCO}_{3}^{-}$is diminished and $\mathrm{Cl}^{-}$secretion dominates. To account for these results, we proposed the above model of anion secretion whereby CFTR serves as the cAMP/PKA-activated anion channel for both
$\mathrm{Cl}^{-}$and $\mathrm{HCO}_{3}^{-}$exit across the apical membrane. Activation of CFTR alone tends to bring $V_{\text {ap }}$ to the equilibrium potential for $\mathrm{Cl}^{-}\left(E_{\mathrm{Cl}}\right)$, a value greater than the equilibrium potential for $\mathrm{HCO}_{3}^{-}\left(\mathrm{E}_{\mathrm{HCO}}\right)$, and thereby provides the driving force for $\mathrm{HCO}_{3}^{-}$exit across the apical membrane. Stimulation by cAMP (forskolin) alone leaves the basolateral membrane potential $\left(V_{\mathrm{bl}}\right)$ less hyperpolarized than the reversal potential of the DNDS-sensitive $\mathrm{NBC}\left(E_{\mathrm{revNBC}}\right)$, and $\mathrm{HCO}_{3}^{-}$ is secreted. Subsequent activation of hIk1 by 1 EBIO or cholinergic agonists hyperpolarizes $V_{\mathrm{bl}}$ so that $V_{\mathrm{bl}}>E_{\text {revNBC, }}$, which inhibits $\mathrm{HCO}_{3}^{-}$uptake by an NBC but provides a driving force for $\mathrm{Cl}^{-}$secretion as $V_{\text {ap }}$ becomes $>E_{\mathrm{Cl}}$.

The initial results that led to the discovery that Calu-3 cells secrete $\mathrm{HCO}_{3}^{-}$in response to cAMP stimulation and $\mathrm{Cl}^{-}$when hIK1 channels are activated by 1-EBIO are illustrated in Figure 2 (Devor et al. 1999). Calu-3 cells were grown on collagen-coated filters and studied by standard short-circuit current $\left(I_{\mathrm{SC}}\right)$ methods. In standard bath solutions of $\mathrm{NaCl}$ and $\mathrm{NaHCO}_{3}$, the Calu-3 cells display a basal $I_{\mathrm{SC}}$ of $13 \pm 0.8 \mu \mathrm{A}$ $\mathrm{cm}^{-2}$ and a transepithelial resistance $\left(R_{\mathrm{t}}\right)$ of 353 $\pm 14 \Omega \mathrm{cm}^{2} \quad(n=216$ filters $)$. Stimulation

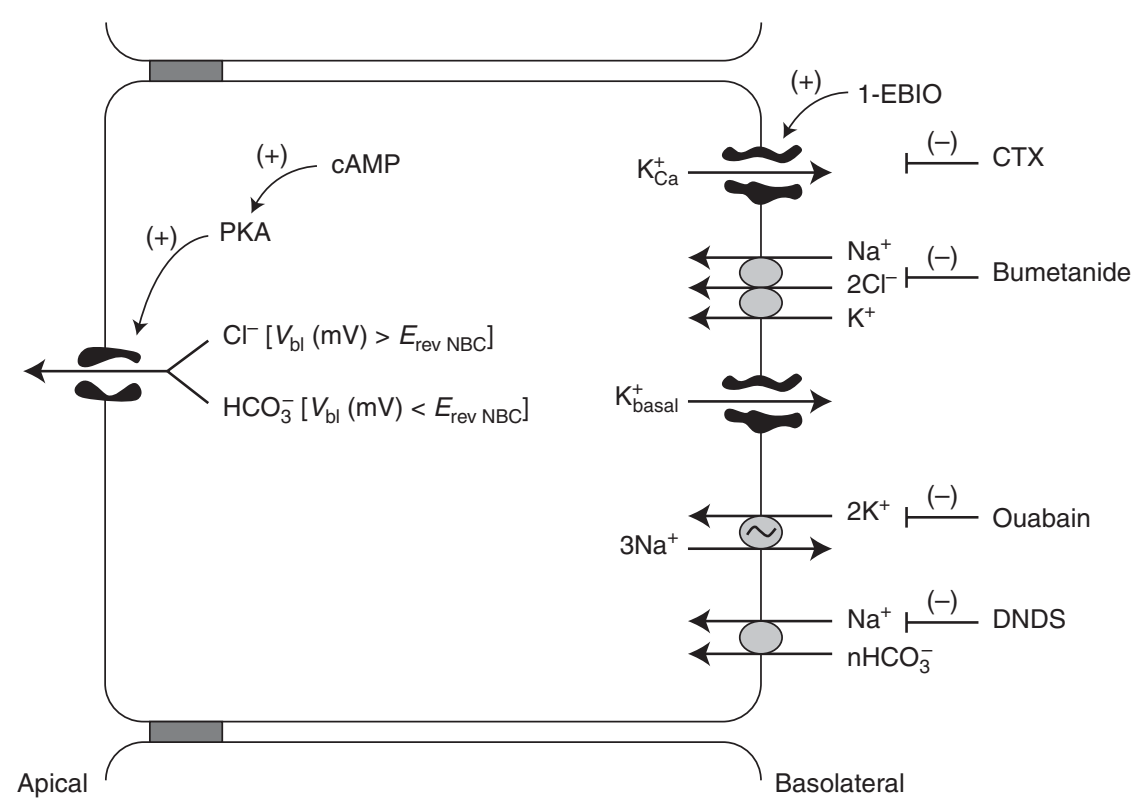

Figure 1. Model of anion secretion in Calu-3 cells. 
A

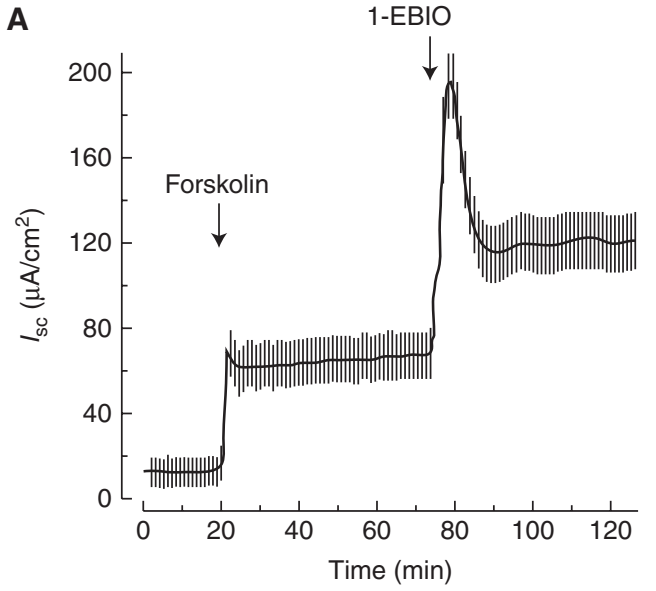

B

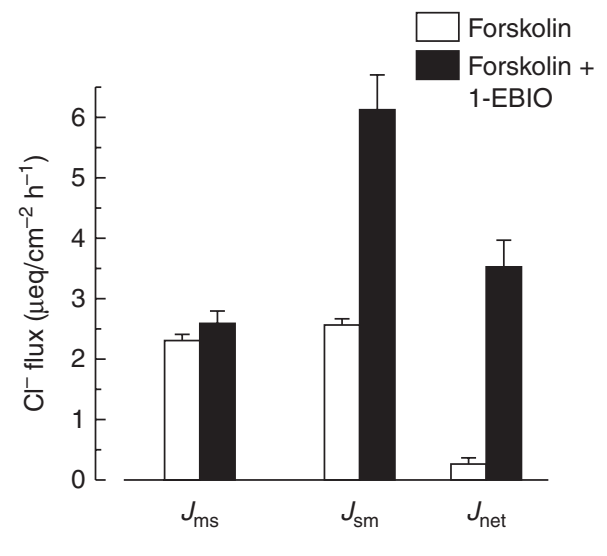

Figure 2. Effect of forskolin $(2 \mu \mathrm{M})$ and 1-EBIO $(1 \mathrm{~mm})$ on $I_{\mathrm{sc}}$ and $\mathrm{Cl}^{-}$fluxes across Calu-3 cells. Ion fluxes are given as absolute values. Forskolin caused a fivefold increase in each of the unidirectional fluxes without any net secretion of $\mathrm{Cl}^{-}$. Control data are not shown. (Figure is from Devor et al. 1999; reprinted, with permission, from the author.)

with forskolin $(2 \mu \mathrm{M})$ induced a damped oscillatory response that became stable and sustained after 5-10 min at a plateau value of $66 \pm 4 \mu \mathrm{A}$ $\mathrm{cm}^{-2}$ and at a reduced $R_{\mathrm{T}}$ of $189 \pm 7 \Omega \mathrm{cm}^{-2}$ $(n=109)$. The subsequent addition of 1 -EBIO $(1 \mathrm{~mm})$ caused a further increase in $I_{\mathrm{SC}}$ to 114 $\pm 5 \mu \mathrm{A} \mathrm{cm}{ }^{-2}$ without any further significant decrease in $R_{\mathrm{t}}\left(173 \pm 9 \Omega \mathrm{cm}^{2}, n=36\right)$. Unidirectional ion fluxes revealed that forskolin caused a fivefold increase in both the mucosalto-serosal and serosal-to-mucosal fluxes of $\mathrm{Cl}^{-}$, but no net secretion of $\mathrm{Cl}^{-}$(Fig. 2B). However, when the forskolin-stimulated monolayers were further stimulated with 1-EBIO, there was a further increase in the serosal-to-mucosal flux of $\mathrm{Cl}^{-}$, and the net secretion of $\mathrm{Cl}^{-}$was nearly equal to the $I_{\mathrm{SC}}$. Moreover, whereas the forskolin-stimulated $I_{\mathrm{SC}}$ and $\mathrm{Cl}^{-}$fluxes were insensitive to bumetanide, bumetanide completely inhibited the $I_{\mathrm{SC}}$ and the net secretion of $\mathrm{Cl}^{-}$in forskolin plus 1-EBIO-treated monolayers (results not shown). Additional ion substitution studies revealed that the forskolin-stimulated $I_{\text {SC }}$ was $\mathrm{Cl}^{-}$independent, $\mathrm{HCO}_{3}^{-}$dependent, and serosal $\mathrm{Na}^{+}$dependent. Pharmacological studies revealed that forskolin-stimulated $I_{\mathrm{SC}}$ was DNDS and acetazolamide sensitive. Collectively, these studies led us to conclude that Calu3 cells secrete $\mathrm{HCO}_{3}^{-}$in response to cAMP stim- ulation. This conclusion was strongly supported by the observation that forskolin stimulation caused an alkalinization of the mucosal bathing solution of Calu-3 cells studied under open circuit conditions. In agreement with our estimates, Wine and coworkers (Irokawa et al. 2004), using a novel chamber to collect the fluid secreted by Calu- 3 cells, showed that forskolin stimulated the secretion of a solution of $\sim 80 \mathrm{~mm}$ $\mathrm{HCO}_{3}^{-}$. Moreover, when forskolin plus 1-EBIO was used to stimulate the cells, the fluid was no longer alkaline, and the $\mathrm{HCO}_{3}^{-}$concentration fell to $17 \mathrm{~mm}$ (Irokawa et al. 2004).

\section{CFTR $\mathrm{CL}^{-}$-DEPENDENT SECRETION}

The studies with 1-EBIO reveal that Calu-3 cells are not limited to $\mathrm{HCO}_{3}^{-}$secretion but can also secrete $\mathrm{Cl}^{-}$. We used 1-EBIO in these studies because it causes a sustained activation of the basolateral membrane $\mathrm{Ca}^{2+}$-activated, CTXsensitive $\mathrm{K}^{+}$channels (hIK1) (Devor et al. 1996a,b; Syme et al. 2000). Although relatively high concentrations of 1-EBIO are required (1 mM), subsequent studies with newly synthesized derivatives that we have prepared with 100-fold higher affinities produce the same effects (Singh et al. 1999). Wine and coworkers (Lee et al. 1998) also observed similar results 


\section{R.J. Bridges}

using thapsigargin to elevate intracellular $\mathrm{Ca}^{2+}$ and activate hIK channels. These channels would normally be activated by $\mathrm{Ca}^{2+}$-mediated agonists such as acetylcholine or substance-P. However, the former does not cause sustained increases in intracellular $\mathrm{Ca}^{2+}$ and $I_{\mathrm{SC}}$. In addition to causing $\mathrm{Cl}^{-}$secretion, the activation of hIK1 channels diminishes $\mathrm{HCO}_{3}^{-}$secretion. These results combined with the observations that forskolin-stimulated $\mathrm{HCO}_{3}^{-}$secretion required serosal $\mathrm{Na}^{+}$and was inhibited by DNDS led us to propose that the influx of $\mathrm{HCO}_{3}^{-}$across the basolateral membrane was mediated by an electrogenic NBC that carries two or more $\mathrm{HCO}_{3}^{-}$ions for each $\mathrm{Na}^{+}$ion. Activation of basolateral membrane $\mathrm{K}^{+}$channels tends to hyperpolarize $V_{\mathrm{bl}}$ and inhibit NBC-dependent $\mathrm{HCO}_{3}^{-}$influx. The hyperpolarization of $V_{\mathrm{bl}}$ also activates the basolateral membrane $\mathrm{NaK} 2 \mathrm{Cl}$-cotransporter (Haas and Forbush 2000), allowing for the influx of $\mathrm{Cl}^{-}$and its net secretion.
Therefore, the activation and inactivation of basolateral membrane $\mathrm{K}^{+}$channels provides a means of switching between $\mathrm{HCO}_{3}^{-}$and $\mathrm{Cl}^{-}$ secretion across airway epithelia as illustrated in Figure 1.

\section{MICROELECTRODE AND IMPEDANCE ANALYSIS STUDIES}

To obtain a better understanding of the conductances and driving forces involved in these different modes of anion secretion in Calu-3 cells, we performed microelectrode and impedance analysis experiments (Tamada et al. 2001). The results of these experiments are summarized in cell models shown in Figure 3. We were able to maintain microelectrode impalements for $10-30 \mathrm{~min}$ on a routine basis in Calu-3 cells, which allowed us to monitor the same cell under control, forskolin, and forskolin plus 1-EBIO-stimulated conditions. Cells were

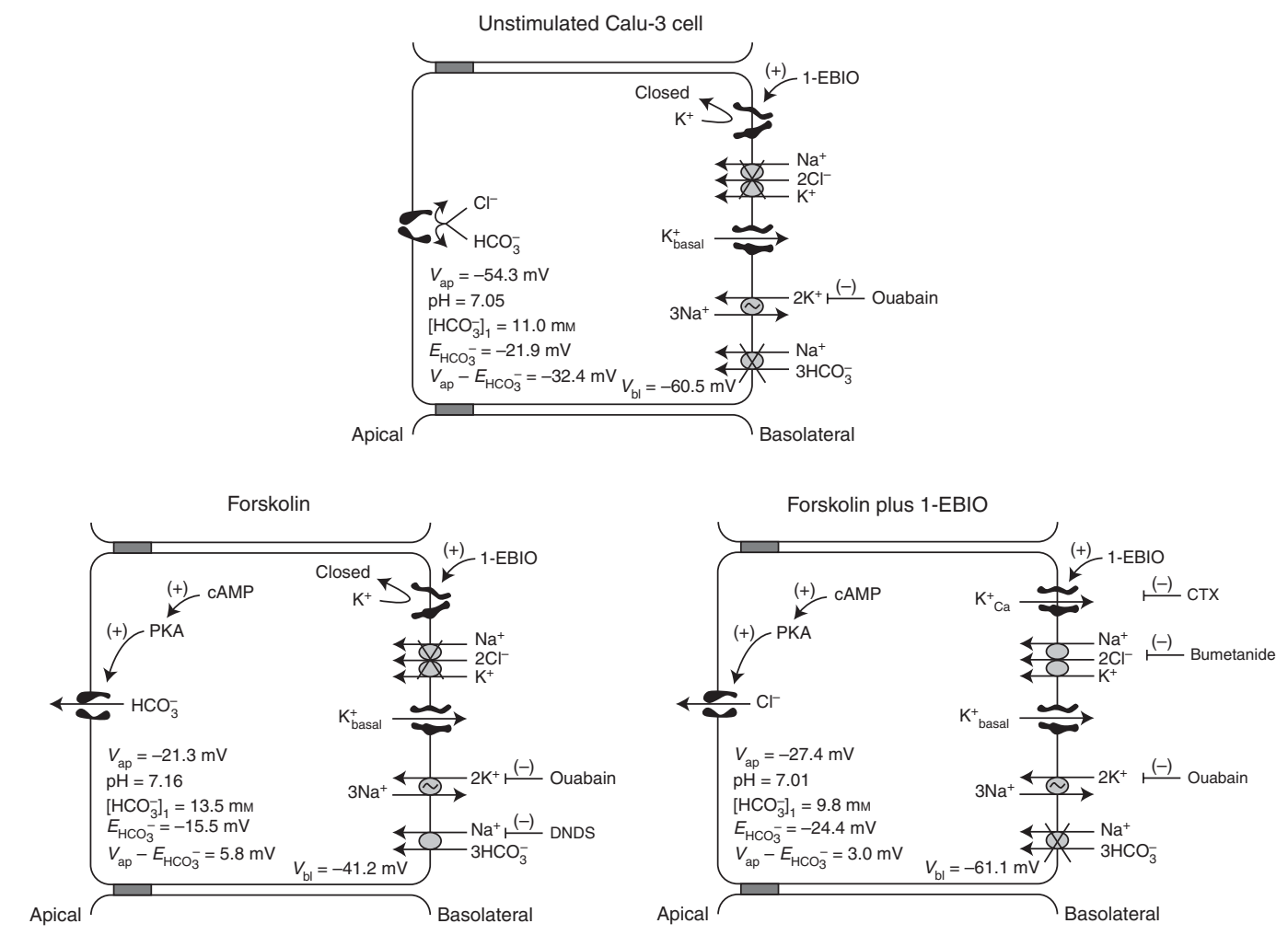

Figure 3. Cell models of unstimulated control cells, forskolin-stimulated cells secreting $\mathrm{HCO}_{3}^{-}$, and forskolin plus 1 -EBIO cells secreting $\mathrm{Cl}^{-}$. See text for details. 
studied under open circuit conditions, and the transepithelial voltage $\left(V_{\mathrm{t}}\right)$ and resistance $\left(R_{\mathrm{t}}\right)$ as well as the $V_{\text {ap }}$ were measured. The apical fractional resistance $\left(F_{\text {Rap }}\right)$ was calculated from the $\Delta V_{\mathrm{t}}$ and the $\Delta V_{\mathrm{ap}} / \Delta V_{\mathrm{t}}$ ratio in response to a 50- $\mu$ A transepithelial pulse and the $V_{\mathrm{bl}}$ from the $V_{\mathrm{t}}$ and $V_{\text {ap }}$ values. Forskolin caused a hyperpolarization of $V_{\mathrm{t}}$ and decreased $R_{\mathrm{t}}$ similar to the changes seen in the short-circuit current experiments yielding equivalent current changes $\left(I_{\mathrm{eq}}\right)$ similar to the previously reported $I_{\mathrm{SC}}$ values of $\sim 65 \mu \mathrm{A} / \mathrm{cm}^{2}$. Forskolin depolarized both $V_{\text {ap }}$ and $V_{\mathrm{bl}} . V_{\mathrm{ap}}$ decreased from a control value in unstimulated cells of $-54.3 \mathrm{mV}$ to $-21.3 \mathrm{mV}$ and $V_{\mathrm{bl}}$ from $-60.5 \mathrm{mV}$ to $-41.2 \mathrm{mV}$. Consistent with the activation of an apical membrane conductance, the $F_{\text {Rap }}$ decreased from 0.55 to 0.074 with forskolin stimulation. Double barrel voltage and $\mathrm{pH}$ electrodes were used to obtain estimates of the intracellular $\mathrm{pH}\left(\mathrm{pH}_{\mathrm{i}}\right)$. Forskolin increased $\mathrm{pH}_{\mathrm{i}}$ from a control value of 7.02 to 7.16. Assuming a $\mathrm{pCO}_{2}$ of $40 \mathrm{~mm} \mathrm{Hg}$, the intracellular $\mathrm{HCO}_{3}^{-}$concentration increased from $11 \mathrm{~mm}$ in control cells to $13.5 \mathrm{~mm}$ in forskolinstimulated cells. Thus, forskolin stimulated a driving force of $5.8 \mathrm{mV}$ for $\mathrm{HCO}_{3}^{-}$exit from the cell. Consistent with the dramatic decrease in the $F_{\text {Rap }}$ impedance analysis showed that the apical membrane resistance fell to $14 \Omega \mathrm{cm}^{2}$ in forskolin-stimulated cells corresponding to an apical membrane conductance of $71 \mathrm{mS} / \mathrm{cm}^{2}$. With a driving force of $5.8 \mathrm{mV}$, only $12 \mathrm{mS} / \mathrm{cm}^{2}$ of the apical membrane conductance of $71 \mathrm{mS} /$ $\mathrm{cm}^{2}$ is needed to account for the observed $\mathrm{HCO}_{3}^{-}$current of $65 \mu \mathrm{A} / \mathrm{cm}^{2}$. The conductance ratio of $12 \mathrm{mS} / \mathrm{cm}^{2}$ to $71 \mathrm{mS} / \mathrm{cm}^{2}$ is 0.17 , and this too is consistent with the reported $\mathrm{HCO}_{3}^{-}$ conductance compared with $\mathrm{Cl}^{-}$of the apical membrane of Calu-3 cells (Illek et al. 1999) as well as CFTR (Linsdell et al. 1997; Tang et al. 2009; Man-song et al. 2010). It must also be noted that a driving force of $5.8 \mathrm{mV}$ does not explain the reported $80 \mathrm{~mm}$ concentration of $\mathrm{HCO}_{3}^{-}$in the thin film experiments (Devor et al. 1999; Irokawa et al. 2004).

It is noteworthy that a driving force of $32.4 \mathrm{mV}$ exists for $\mathrm{HCO}_{3}^{-}$exit in unstimulated control cells, and yet not until CFTR is activated is $\mathrm{HCO}_{3}^{-}$secreted, and this secretion is driven by a much lower driving force $(5.8 \mathrm{mV})$. Thus, if alternative $\mathrm{HCO}_{3}^{-}$transporters are present in the apical membrane, they are not active until the cells are stimulated with forskolin. In addition, the intracellular $\mathrm{HCO}_{3}^{-}$concentration is actually increased in forskolin-stimulated cells, indicating that the secreted $\mathrm{HCO}_{3}^{-}$is replenished. We surmise that $\mathrm{HCO}^{-}$entry via a basolateral membrane $\mathrm{NBC}$ is activated by depolarization of the basolateral membrane. Given a reversal potential for an NBC with a stoichiometry of $1 \mathrm{Na}^{+}$to $2 \mathrm{HCO}_{3}^{-}$of nearly $-90 \mathrm{mV}$, we suggested that the $\mathrm{NBC}$ that mediates $\mathrm{HCO}_{3}^{-}$entry has a stoichiometry of $1 \mathrm{Na}^{+}$to $3 \mathrm{HCO}_{3}^{-}$with a reversal potential of approximately $-60 \mathrm{mV}$. Depolarization of $V_{\mathrm{bl}}$ from $-61.5 \mathrm{mV}$ in unstimulated cells to $-44 \mathrm{mV}$ would activate an NBC with a 1:3 stoichiometry. Addition of DNDS to the basolateral side caused a depolarization of $8.5 \mathrm{mV}$ in forskolin-stimulated cells but not in unstimulated cells. Replacement of $\mathrm{HCO}_{3}^{-}$with HEPES also depolarized $V_{\mathrm{bl}}$ by $8.5 \mathrm{mV}$ (T Tamada and RJ Bridges, unpubl.). These results are consistent with the activation of an electrogenic, DNDS-sensitive basolateral membrane NBC in forskolin-stimulated cells. Confirmation of the exact stoichiometry of the NBC will require measurements of the intracellular $\mathrm{Na}^{+}$activity.

The microelectrode and impedance studies revealed that 1-EBIO hyperpolarized $V_{\mathrm{bl}}$ and $V_{\mathrm{ap}}$ when added to forskolin-stimulated cells. $V_{\mathrm{bl}}$ hyperpolarized from $-41.2 \mathrm{mV}$ to $-61.1 \mathrm{mV}$ and $V_{\text {ap }}$ from $-21.3 \mathrm{mV}$ to $-27.4 \mathrm{mV}$ when 1 EBIO was added to the forskolin-stimulated cells. The hyperpolarization caused by 1 -EBIO was reversed by the addition of hIK1 blockers ( $\mathrm{T}$ Tamada and RJ Bridges, unpubl.). Impedance analysis confirmed that 1 -EBIO activated a basolateral membrane conductance, and the reversal of this conductance increased with hIK-1 blockers. 1-EBIO also decreased $\mathrm{pH}_{\mathrm{i}}$ from 7.16 to 7.01, and intracellular $\mathrm{HCO}_{3}^{-}$from 13.5 to $9.8 \mathrm{~mm}$. $V_{\mathrm{bl}}$ was no longer sensitive to DNDS or to serosal $\mathrm{HCO}_{3}^{-}$replacement with HEPES. However, bumetanide decreased $V_{\mathrm{t}}$, and as noted above, the current was almost fully accounted for by $\mathrm{Cl}^{-}$secretion in forskolin plus 1-EBIO-stimulated cells. These results are 
R.J. Bridges

consistent with the activation of basolateral membrane hIK-1 potassium channels. For an $\mathrm{NBC}$ with a $1: 3 \mathrm{Na}^{+}$-to- $\mathrm{HCO}_{3}^{-}$stoichiometry, the hyperpolarization of $V_{\mathrm{bl}}$ to -61.1 exceeds the reversal potential of the $\mathrm{NBC}$ and thereby would allow $\mathrm{HCO}_{3}^{-}$exit from the cell on the NBC. Consequently, both $\mathrm{pH}_{\mathrm{i}}$ and intracellular $\mathrm{HCO}_{3}^{-}$decrease. Even though the $\mathrm{pH}_{\mathrm{i}}$ and intracellular $\mathrm{HCO}_{3}^{-}$have decreased, a driving force of $3.0 \mathrm{mV}$ still exists for $\mathrm{HCO}_{3}^{-}$exit across the apical membrane. If cell metabolism produces sufficient $\mathrm{HCO}_{3}^{-}$, then $\mathrm{HCO}_{3}^{-}$secretion should persist. Indeed, acetazolamide causes a small decrease in the $I_{\mathrm{SC}}$ in forskolin plus 1-EBIO-stimulated cells.

1-EBIO also appears to activate the basolateral membrane NKCC cotransporter. Activation of the NKCC may result from the hyperpolarization of $V_{\mathrm{bl}}$ as well as cell shrinkage due to the loss of intracellular $\mathrm{Cl}^{-}$and $\mathrm{K}^{+}$(Haas and Forbush 2000). Impedance analysis and cell height measurements confirm that Calu-3 cells shrink when 1-EBIO is added to forskolin-stimulated cells (RJ Bridges and W van Driessche, unpubl.). Addition of 1-EBIO also hyperpolarizes $V_{\text {ap }}$ in forskolin-stimulated cells. If intracellular $\mathrm{Cl}^{-}$were to remain unchanged in forskolin- and forskolin plus 1-EBIO-stimulated cells, a driving force of $6.1 \mathrm{mV}$ would exist for $\mathrm{Cl}^{-}$ exit across the apical membrane. A 6.1-mV driving force across an apical membrane conductance of $71 \mathrm{mS} / \mathrm{cm}^{2}$ should result in a current of $433 \mu \mathrm{A} / \mathrm{cm}^{2}$. Because we observe a $\mathrm{Cl}^{-}$ current of only $\sim 140 \mu \mathrm{A} / \mathrm{cm}^{2}$, we predict that the intracellular $\mathrm{Cl}^{-}$concentration must decrease by $8 \mathrm{~mm}$ when 1 -EBIO is added to the forskolin-stimulated cells. Unfortunately, we were unsuccessful in our attempts to fabricate a double barrel voltage and chloride-sensitive microelectrode to test this hypothesis.

\section{SUMMARY}

Calu-3 cells, an airway serous cell model with high levels of CFTR expression, secrete $\mathrm{HCO}_{3}^{-}$ in response to a cAMP-mediated agonist but can be stimulated to secrete $\mathrm{Cl}^{-}$with a basolateral membrane $\mathrm{K}^{+}$channel-activating agonist such as 1-EBIO. Activation of CFTR by for- skolin results in a very high apical membrane conductance and a depolarization of $V_{\text {ap }}$ to a value that approaches $E_{\mathrm{Cl}}$. With $V_{\mathrm{ap}}$ at $E_{\mathrm{Cl}}$, there is a net driving force for $\mathrm{HCO}_{3}^{-}$exit from the cell across the apical membrane. Because of this driving force and the very high apical membrane conductance, $\mathrm{HCO}_{3}^{-}$can be secreted from the cells despite the lower conductance of CFTR for $\mathrm{HCO}_{3}^{-}$compared with $\mathrm{Cl}^{-}$. The very high apical membrane anion conductance also results in a depolarization of $V_{\mathrm{bl}}$ and the activation of a basolateral membrane NBC. Secreted $\mathrm{HCO}_{3}^{-}$is supplied by the basolateral entry of $\mathrm{HCO}_{3}^{-}$by this NBC. Thus, the activation of CFTR sets the $V_{\text {ap }}$ at $E_{\mathrm{Cl}}$, provides the driving force for $\mathrm{HCO}_{3}^{-}$ exit, and results in the activation of a basolateral membrane NBC. Activation of basolateral membrane $\mathrm{K}^{+}$channels hyperpolarizes $V_{\mathrm{bl}}$ and $V_{\text {ap. }}$. The hyperpolarization of $V_{\text {ap }}$ provides a driving force for $\mathrm{Cl}^{-}$secretion. The hyperpolarization of $V_{\mathrm{bl}}$ results in an inhibition of the NBC and the activation of the NKCC. Therefore, the switch from $\mathrm{HCO}_{3}^{-}$secretion to $\mathrm{Cl}^{-}$secretion is mediated by the activity of the basolateral $\mathrm{K}^{+}$ channel and which of the basolateral membrane cotransporters is active, NBC or the NKCC. Depending on which of these cotransporters is active, CFTR will secret either $\mathrm{HCO}_{3}^{-}$or $\mathrm{Cl}^{-}$.

\section{ACKNOWLEDGMENTS}

I thank my collaborators Dr. Dan Devor, Dr. Tsutomu Tamada, Dr. Martin Hug, Dr. Jim Kreindler, Dr. Willy van Driessche, and Dr. Raymond Frizzell for their many helpful discussions and contributions during the course of these studies. The skillful technical assistance of Mathew Green and Ashwini Mokashi as well as the secretarial assistance of Kim Hankin are acknowledged. Special thanks go to Dr. Paul Quinton, who encouraged me to prepare this article and waited very patiently for its completion.

\section{REFERENCES}

\section{${ }^{*}$ Reference is also in this collection.}

Al-Bazzaz FJ. 1981. Role of cyclic AMP in regulation of chloride secretion by canine tracheal mucosa. Am Rev Respir Dis 123: 295-298. 
Al-Bazzaz FJ, Al Awqati Q. 1979. Interaction between sodium and chloride transport in canine tracheal mucosa. J App Physiol 46: 111-119.

Al-Nakkash L, Hwang TC. 1999. Activation of wild-type and $\triangle$ F508-CFTR by phosphodiesterase inhibitors through cAMP-dependent and -independent mechanisms. Pflugers Arch 437: 553-561.

Basbaum CB, Jany B, Finkbeiner WE. 1990. The serous cell. Annu Rev Physiol 52: 97-113.

Berger JT, Voynow JA, Peters KW, Rose MC. 1999. Respiratory carcinoma cell lines. MUCgenes and glycoconjugates. Am J Respir Cell Mol Biol 20: 500-510.

Boucher RC. 1994a. Human airway ion transport. Part one. Am J Respir Crit Care Med 150: 271-281.

Boucher RC. 1994b. Human airway ion transport. Part two. Am J Respir Crit Care Med 150: 581-593.

Boucher RC. 2007. Airway surface dehydration in cystic fibrosis: Pathogenesis and therapy. Annu Rev Med 58: 157-170.

Boucher RC, Stutts MJ, Knowles MR, Cantley L, Gatzy JT. 1986. $\mathrm{Na}^{+}$transport in cystic fibrosis respiratory epithelia. Abnormal basal rate and response to adenylate cyclase activation. J Clin Invest 78: 1245-1252.

Boucher RC, Cotton CU, Gatzy JT, Knowles MR, Yankaskas JR. 1988. Evidence for reduced $\mathrm{Cl}^{-}$and increased $\mathrm{Na}^{+}$ permeability in cystic fibrosis human primary cell cultures. J Physiol 405: 77-103.

Celli BR, Snider GL, Heffner J, Tiep B, Ziment I, Make B, Braman S, Olsen G, Phillips Y. 1995. Standards for the diagnosis and care of patients with chronic obstructive pulmonary disease. Am J Respir Crit Care Med 152: S77-S120

Corrales RJ, Nadel JA, Widdicombe JH. 1984. Source of the fluid component of secretions from tracheal submucosal glands in cats. J Appl Physiol 56: 1076-1082.

Devor DC, Singh AK, Frizzell RA, Bridges RJ. 1996a. Modulation of $\mathrm{Cl}^{-}$secretion by benzimidazolones. I. Direct activation of a Ca ${ }^{2+}$-dependent $\mathrm{K}^{+}$channel. Am J Physiol 271: L775-L784.

Devor DC, Singh AK, Bridges RJ, Frizzell RA. 1996b. Modulation of $\mathrm{Cl}^{-}$secretion by benzimidazolones. II. Coordinate regulation of apical $\mathrm{GCl}$ and basolateral GK. Am J Physiol 271: L785-L795.

Devor DC, Singh AK, Lambert LC, DeLuca A, Frizzell RA, Bridges RJ. 1999. Bicarbonate and chloride secretion in Calu-3 human airway epithelial cells. J Gen Physiol 113: 743-760.

Duszyk M, Shu Y, Sawicki G, Radomski A, Man SF, Radomski MW. 1999. Inhibition of matrix metalloproteinase MMP-2 activates chloride current in human airway epithelial cells. Can J Physiol Pharmacol 77: 529-535.

Engelhardt JF, Zepeda M, Cohn JA, Yankaskas JR, Wilson JM. 1994. Expression of the cystic fibrosis gene in adult human lung. J Clin Invest 93: 737-749.

Finkbeiner WE, Carrier SD, Teresi CE. 1993. Reverse transcription-polymerase chain reaction (RT-PCR) phenotypic analysis of cell cultures of human tracheal epithelium, tracheobronchial glands, and lung carcinomas. Am J Respir Cell Mol Biol 9: 547-556.
Forstner JF, Jabbal I, Findlay BP, Forstner GG. 1976. Interaction of mucins with calcium, $\mathrm{H}^{+}$ion and albumin. Mod Probl Paediatr 19: 54-65.

Gaskin KJ, Durie PR, Corey M, Wei P, Forstner GG. 1982. Evidence for a primary defect of pancreatic $\mathrm{HCO}_{3}^{-}$secretion in cystic fibrosis. Pediatr Res 16: 554-557.

Gray MA, Pollard CE, Harris A, Coleman L, Greenwell JR, Argent BE. 1990. Anion selectivity and block of the smallconductance chloride channel on pancreatic duct cells. Am J Physiol 259: C752-C761.

Grygorczyk R, Hanrahan JW. 1997. CFTR-independent ATP release from epithelial cells triggered by mechanical stimuli. Am J Physiol 272: C1058-C1066.

Haas M, Forbush B III. 2000. The Na-K-Cl cotransporter of secretory epithelia. Annu Rev Physiol 62: 515-534.

Hadorn B, Johansen PG, Anderson CM. 1968. Pancreozymin secretin test of exocrine pancreatic function in cystic fibrosis and the significance of the result for the pathogenesis of the disease. Can Med Assoc J 98: 377-385.

Illek B, Tam AW, Fischer H, Machen TE. 1999. Anion selectivity of apical membrane conductance of Calu-3 human airway epithelium. Pflugers Arch 437: 812-822.

Inglis SK, Corboz MR, Taylor AE, Ballard ST. 1997. Effect of anion transport inhibition on mucus secretion by airway submucosal glands. Am J Physiol 272: L372-L377.

Inglis SK, Corboz MR, Ballard ST. 1998. Effect of anion secretion inhibitors on mucin content of airway submucosal gland ducts. Am J Physiol 274: L762-L766.

Irokawa T, Krouse ME, Joo NS, Wu JV, Wine JJ. 2004. A "virtual gland" method for quantifying epithelial fluid secretion. Am J Physiol Lung Cell Mol Physiol 287: L784-L793.

Ishiguro H, Steward MC, Wilson RW, Case RM. 1996a. Bicarbonate secretion in interlobular ducts from guineapig pancreas. J Physiol 495: 179-191.

Ishiguro H, Steward MC, Lindsay AR, Case RM. 1996b. Accumulation of intracellular $\mathrm{HCO}_{3}^{-}$by $\mathrm{Na}^{+}-\mathrm{HCO}_{3}^{-}$ cotransport in interlobular ducts from guinea-pig pancreas. J Physiol 495: 169-178.

Ishiguro $\mathrm{H}$, Steward MC, Naruse S, Ko SBH, Goto H, Case RM, Kondo T, Yamamoto A. 2009. CFTR functions as a bicarbonate channel in pancreatic duct cells. J Gen Physiol 133: 315-326.

Ito Y, Kume H, Yamaki K, Takagi K. 1999. Tetracyclines reduce $\mathrm{Na}^{+} / \mathrm{K}^{+}$pump capacity in Calu-3 human airway cells. Biochem Biophys Res Commun 260: 13-16.

Joo NS, Irokawa T, Robbins RC, Wine JJ. 2006. Hyposecretion, not hyperabsorption, is the basic defect of cystic fibrosis airway glands. J Biol Chem 281: 7392-7398.

Kelley TJ, al-Nakkash L, Drumm ML. 1995. CFTR-mediated chloride permeability is regulated by type III phosphodiesterases in airway epithelial cells. Am J Respir Cell Mol Biol 13: 657-664.

Kopelman H, Durie P, Gaskin K, Weizman Z, Forstner G. 1985. Pancreatic fluid secretion and protein hyperconcentration in cystic fibrosis. N Engl J Med 312: 329-334.

Kopelman H, Corey M, Gaskin K, Durie P, Weizman Z, Forstner G. 1988. Impaired chloride secretion, as well as bicarbonate secretion, underlies the fluid secretory defect in the cystic fibrosis pancreas. Gastroenterology 95: 349-355. 
R.J. Bridges

Kreindler JL, Peters KW, Frizzell RA, Bridges RJ. 2006. Identification and membrane localization of electrogenic sodium bicarbonate cotransporters in Calu-3 cells. Biochim Biophys Acta 1762: 704-710.

Lee MC, Penland CM, Widdicombe JH, Wine JJ. 1998. Evidence that Calu-3 human airway cells secrete bicarbonate. Am J Physiol 274: L450-L453.

Li M-S, Holstead RG, Wang W, Linsdell P. 2011. Regulation of CFTR chloride channel macroscopic conductance by extracellular bicarbonate. Am J Physiol Cell Physiol 300: C65-C74.

Liedtke CM, Cole TS. 1998. Antisense oligonucleotide to PKC- $\varepsilon$ alters cAMP-dependent stimulation of CFTR in Calu-3 cells. Am J Physiol 275: C1357-C1364.

Lin SY, Amidon GL, Weiner ND, Goldberg AH. 1993. Viscoelasticity of anionic polymers and their mucociliary transport on the frog palate. Pharm Res 10: 411-417.

Linsdell P, Tabcharani JA, Hanrahan JW. 1997. Multi-ion mechanism for ion permeation and block in the cystic fibrosis transmembrane conductance regulator chloride channel. J Gen Physiol 110: 365-377.

List SJ, Findlay BP, Forstner GG, Forstner JF. 1978. Enhancement of the viscosity of mucin by serum albumin. Biochem J 175: 565-571.

Marino CR, Matovcik LM, Gorelick FS, Cohn JA. 1991 Localization of the cystic fibrosis transmembrane conductance regulator in pancreas. J Clin Invest 88: 712-716.

O’Byrine PM, Postma DS. 1999. The many faces of airway inflammation: Asthma and chronic obstructive pulmonary disease. Am J Respir Crit Care Med 159: S41-S66.

Puchelle E, Gaillard D, Ploton D, Hinnrasky J, Fuchey C, Boutterin MC, Jacquot J, Dreyer D, Pavirani A, Dalemans W. 1992. Differential localization of the cystic fibrosis transmembrane conductance regulator in normal and cystic fibrosis airway epithelium. Am J Respir Cell Mol Biol 7: 485-491.

Quinton PM. 1999. Physiological basis of cystic fibrosis: A historical perspective. Physiol Rev 79: S3-S22.

Randell SH, Boucher RC. 2006. Effective mucus clearance is essential for respiratory health. Am J Respir Cell Mol Biol 35: $20-28$

Salinas D, Haggie PM, Thiagarajah JR, Song Y, Rosbe K, Finkbeiner WE, Nielson DW, Verkman AS. 2005. Submucosal gland dysfunction as a primary defect in cystic fibrosis. FASEB J 19: 431-433.

Schultz I. 1987. Electrolyte and fluid secretion in the exocrine pancreas. In Physiology of the gastrointestinal tract (ed. Johnson LR), Vol. 2, pp. 1147-1172. Raven, New York.

Shen BQ, Finkbeiner WE, Wine JJ, Mrsny RJ, Widdicombe JH. 1994. Calu-3: A human airway epithelial cell line that shows cAMP-dependent $\mathrm{Cl}^{-}$secretion. Am J Physiol 266: L493-L501.

Singh S, Syme CA, Singh AK, Devor DC, Bridges RJ. 1999. Development of benzimidazolones as chloride secretory agonists. Ped Pulmonl Suppl 19: 190.

Smith JJ, Welsh MJ. 1992. cAMP stimulates bicarbonate secretion across normal, but not cystic fibrosis airway epithelia. J Clin Invest 89: 1148-1153.

Song Y, Salinas D, Nielson DW, Verkman AS. 2006. Hyperacidity of secreted fluid from submucosal glands in early cystic fibrosis. Am J Physiol Cell Physiol 290: C741-C749.

Syme CA, Gerlach AC, Singh AK, Devor DC. 2000. Pharmacological activation of cloned intermediate- and smallconductance $\mathrm{Ca}^{2+}$-activated $\mathrm{K}^{+}$channels. Am J Physiol Cell Physiol 278: C570-C581.

Tam PY, Verdugo P. 1981. Control of mucus hydration as a Donnan equilibrium process. Nature 292: 340-342.

Tamada T, Hug MJ, Frizzell RA, Bridges RJ. 2001. Microelectrode and impedance analysis of anion secretion in Calu-3 cells. JOP 2: 219-228.

Tang L, Fatehi M, Linsdell P. 2009. Mechanism of direct bicarbonate transport by the CFTR anion channel. J Cyst Fibros 8: 115-121.

Trout L, King M, Feng W, Inglis SK, Ballard ST. 1998. Inhibition of airway liquid secretion and its effect on the physical properties of airway mucus. Am J Physiol 274: L258-L263.

* Verdugo P. 2012. Supramolecular dynamics of mucus. Cold Spring Harb Perspect Med doi: 10.1101/cshperspect. a009597.

Waters CM, Savla U. 1999. Keratinocyte growth factor accelerates wound closure in airway epithelium during cyclic mechanical strain. J Cell Physiol 181: 424-432.

Welsh MJ. 1983. Inhibition of chloride secretion by furosemide in canine tracheal epithelium. $J$ Membr Biol 71: 219-226.

Willumsen NJ, Boucher RC. 1992. Intracellular pH and its relationship to regulation of ion transport in normal and cystic fibrosis human nasal epithelia. J Physiol 455: 247-269.

Willumsen NJ, Davis CW, Boucher RC. 1989a. Intracellular $\mathrm{Cl}^{-}$activity and cellular $\mathrm{Cl}^{-}$pathways in cultured human airway epithelium. Am J Physiol 256: C1033-C1044.

Willumsen NJ, Davis CW, Boucher RC. 1989b. Cellular $\mathrm{Cl}^{-}$ transport in cultured cystic fibrosis airway epithelium. Am J Physiol 256: C1045-C1053.

Yeates DB, Besseris GJ, Wong LB. 1997. Physiochemical properties of mucus and its propulsion. In The lung, scientific foundations, 2nd ed. (ed. Crystal RG), pp. 487-515. Lippincott Williams \& Wilkins, New York. 


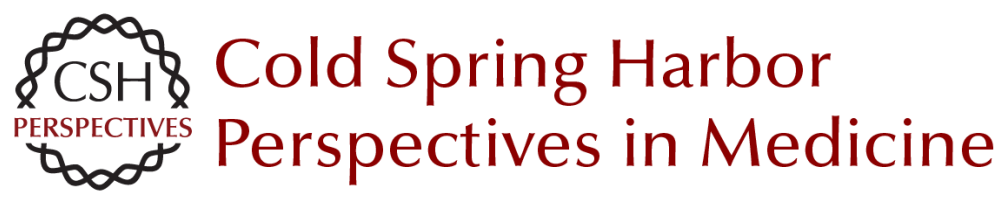

\section{Mechanisms of Bicarbonate Secretion: Lessons from the Airways}

Robert J. Bridges

Cold Spring Harb Perspect Med 2012; doi: 10.1101/cshperspect.a015016

Subject Collection

For additional articles in this collection, see http://perspectivesinmedicine.cshlp.org/cgi/collection/ 